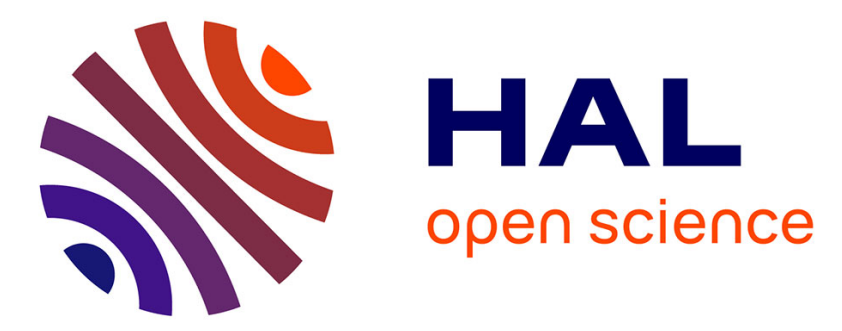

\title{
Inheritance of fruit quality traits in apricot progenies
}

D Ruiz, L. Dondini, J.A. Salazar, Stefano Tartarini, M.D. Nortes, P.

Martínez-Gómez, J. Egea, Guy Clauzel, Patrick Lambert, Alain Blanc, et al.

\section{To cite this version:}

D Ruiz, L. Dondini, J.A. Salazar, Stefano Tartarini, M.D. Nortes, et al.. Inheritance of fruit quality traits in apricot progenies. 15. International Symposium on Apricot Breeding and Culture, Jun 2011, Yerevan, Armenia. hal-02749079

\section{HAL Id: hal-02749079 \\ https://hal.inrae.fr/hal-02749079}

Submitted on 3 Jun 2020

HAL is a multi-disciplinary open access archive for the deposit and dissemination of scientific research documents, whether they are published or not. The documents may come from teaching and research institutions in France or abroad, or from public or private research centers.
L'archive ouverte pluridisciplinaire HAL, est destinée au dépôt et à la diffusion de documents scientifiques de niveau recherche, publiés ou non, émanant des établissements d'enseignement et de recherche français ou étrangers, des laboratoires publics ou privés. 


\section{ЈU도 \\ XV International \\ Symposium \\ $20-24$ \\ on Apricot Breeding \\ and Culture}

PISHS

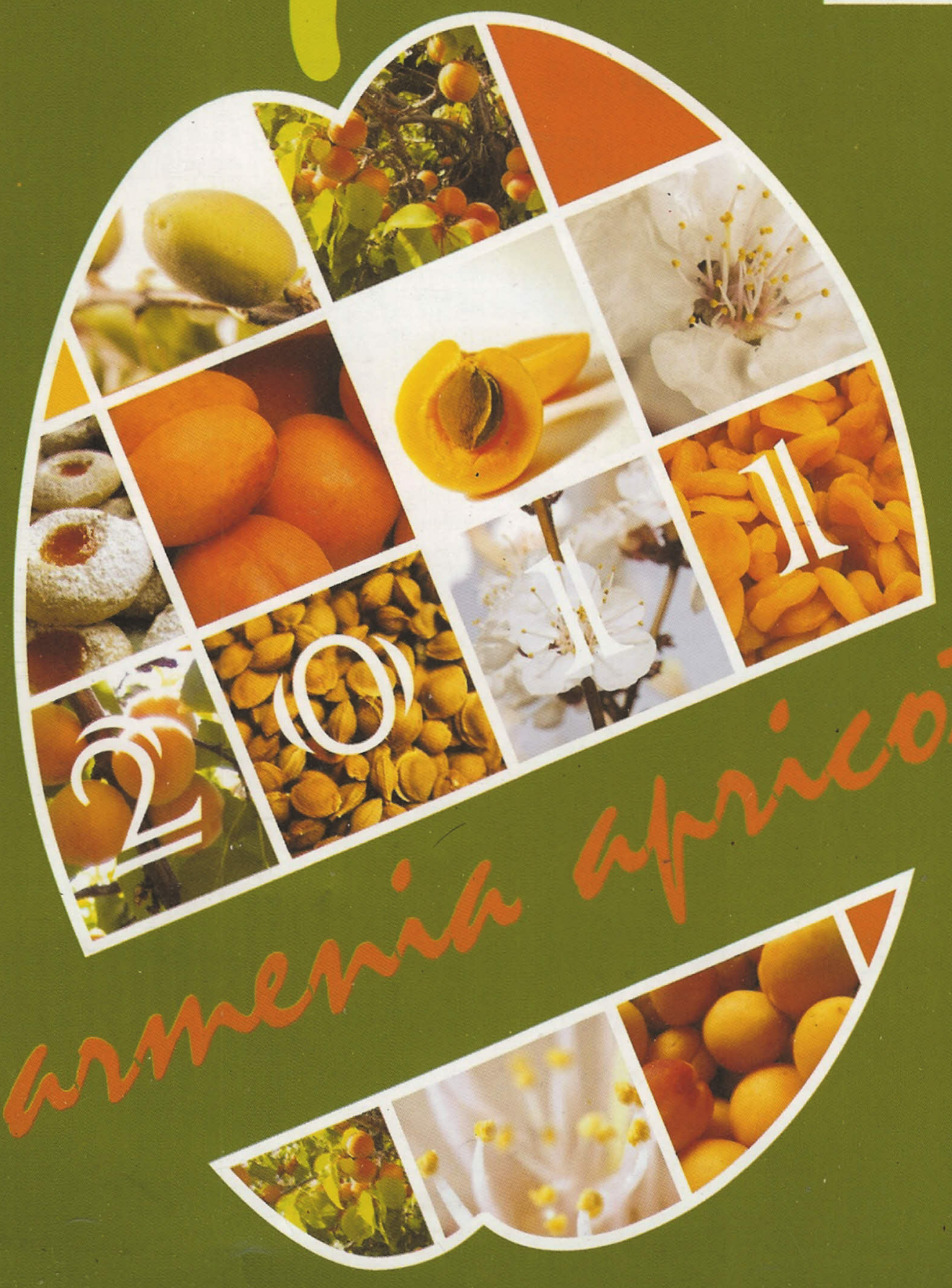




\section{INHERITANCE OF FRUIT QUALITY TRAITS IN APRICOT PROGENIES}

D. Ruiz ${ }^{1}$, L. Dondini ${ }^{2}$, J.A. Salazar ${ }^{1}$, S. Tartarini ${ }^{2}$, M.D. Nortes ${ }^{1}$, P. MartínezGómez $^{1}$, J. Egea ${ }^{1}$, G. Clauzel ${ }^{3}$, P. Lambert ${ }^{3}$, A. Blanc ${ }^{3}$, S. Bureau ${ }^{4}$, M. Reich ${ }^{4}$, P. Reiling ${ }^{4}$, B. Gouble ${ }^{4}$, C.M.G.C. Renard ${ }^{4}$ and J.M. Audergon ${ }^{3}$

${ }^{1}$ CEBAS-CSIC, Department of Plant Breeding, E-30100, Murcia, Spain

${ }^{2}$ Univiversity Bologna, Departamento Colture Arboree, I-40126 Bologna, Italy

${ }^{3}$ INRA, Unité de Génétique et d'Amélioration des Fruits et Légumes, F-84143 Montfavet, France

${ }^{4}$ INRA-UMR 408, Sécurité et Qualité des Produits d'Origine Végétale, INRA-Université d'Avignon, F-84000 Avignon, France

The knowledge on the transmission of fruit quality traits has a great importance in order to optimize the inter-variety crosses design and to improve the efficiency of apricot breeding programmes. Four apricot progenies coming from different genetic origins were evaluated during two years; two apricot progenies cultivated in Avignon (France), one in Bologna (Italy), and other one in Murcia (Spain). Fruit quality characterization was based on physical measurements (fruit weight, colour, and firmness) and biochemical measurements (soluble solids content, and titratable acidity). Phenotypic datasets showed distribution of seedlings with regard to the parents, with a high variability for all analyzed quality parameters. An inter-annual variation was observed for the mean values of all the genotypes between the two years of the study, indicating the influence of the environmental conditions on fruit characteristics. Results indicated a quantitative inheritance of all quality traits in the apricot progenies indicating their polygenic nature. In general we have observed a normal distribution of quality traits in the populations. However, in contrast to intermediate expected values between the parents, a large number of seedlings showed lower or higher values than their parents for many quality parameters. In this sense, results evidenced an extra genetic influence of the parents (the whole genetic background) on the transmission of fruit quality traits in apricot, which should be taken into consideration when inter-variety crosses design.

Corresponding author: D. Ruiz, Email: druiz@cebas.csic.es 